\title{
Embryo Production of Two Sympatric Snapping Shrimps of the Genus Alpheus (Caridea: Alpheidae) from Northeastern Brazil: a Comparative Approach
}

\author{
Guidomar Oliveira Soledade ${ }^{1,2} \cdot$ Patricia Souza Santos $^{1,2} \cdot$ Régis Augusto Pescinelli $^{3}$. \\ Rogério Caetano Costa ${ }^{3}$ - Alexandre Oliveira Almeida ${ }^{1,2}$
}

Received: 15 February 2017 / Published online: 27 June 2017

(C) Springer International Publishing AG 2017

\begin{abstract}
In spite of the high number of species ( 300) and their wide geographic distribution, studies on reproductive biology have only been conducted with a few species of the genus Alpheus Fabricius 1798. The objective of this study was to compare the characteristics of embryo production of two sympatric species of shrimps, Alpheus buckupi Almeida, Terossi, Araújo-Silva \& Mantelatto, Zootaxa 3652:437-452, 2013a and A. carlae Anker, Zootaxa 3386:1-109, 2012. Brooding females were collected in two sites on the coast of Bahia, northeastern Brazil, between July 2012 and May 2013. Female's carapace length (CL) was measured and their embryos were classified according to stage of development. A total of 47 females of A. buckupi (mean CL $9.4 \pm 1.0 \mathrm{~mm}$ ) and 36 of A. carlae (mean CL $8.6 \pm 1.3 \mathrm{~mm}^{3}$ ) were sampled. Fecundity was positively correlated with CL in both species. Fecundity was higher $(117 \pm 80)$ in A. buckupi, which also produced smaller embryos $\left(0.10 \pm 0.03 \mathrm{~mm}^{3}\right)$ than $A$. carlae $\left(0.13 \pm 0.03 \mathrm{~mm}^{3}\right.$; fecundity: $\left.50 \pm 58\right)$. The reproductive output (RO) of A. buckupi and A. carlae was similar, $0.05 \pm 0.06$
\end{abstract}

Guidomar Oliveira Soledade

guidoosoledade@gmail.com

1 Laboratory of Crustacean Biology (LBC), Department of Zoology, Biosciences Center, Federal University of Pernambuco, Av. Prof. Moraes Rêgo, 1235, Cidade Universitária, Recife, Pernambuco 50670-901, Brazil

2 Postgraduate Program in Animal Biology, Department of Zoology, Center for Biosciences, Universidade Federal de Pernambuco, Avenida Prof. Moraes Rêgo, 1235, Cidade Universitária, Recife, Pernambuco 50670-901, Brazil

3 Laboratory of Biology of Marine and Freshwater Shrimps (LABCAM), Department of Biological Sciences, Faculty of Sciences, São Paulo State University (UNESP), Av. Eng. Luiz Edmundo Carrijo Coube, 14-01, Bauru, SP 17033-360, Brazil and $0.04 \pm 0.02$, respectively. The fecundity and reproductive output of both species were lower than those reported for other alpheids. Our results indicated that sympatric lineages differ regarding reproductive features, suggesting that different selective forces influenced fecundity in these snapping shrimps. This study provides the first insights on the embryo production of A. buckupi in the Western Atlantic and of A. carlae in northeastern Brazil.

Keywords Crustacea $\cdot$ Reproduction $\cdot$ Maternal output . Embryo volume

\section{Introduction}

Reproductive strategies vary widely among crustaceans (Hartnoll 1985) and are controlled by the interaction of intrinsic (phylogenetic component) and extrinsic (environmental component) factors. Factors such as mode of larval development, body size, periodicity of spawning throughout the year and food availability may determine reproductive traits such as embryo size and fecundity (Sastry 1983; Hartnoll 1985).

The caridean shrimps of the family Alpheidae Rafinesque 1815 show a high morphological, ecological, and behavioral heterogeneity. They are widely distributed in the Indo-West Pacific, East Pacific and across the Atlantic, with estimates of about 600 species (Chace 1988; Anker et al. 2006). Alpheids occur from the intertidal zone to the deep sea of tropical and subtropical, inhabiting various marine and estuarine ecosystems (e. g., mangroves, coral reefs, stygobitic habitats), and few are adapted to oligohaline and freshwater habitats (Anker et al. 2006). Despite the large information available on this family, studies on their reproductive biology have focused in a few species of the genera Alpheus Fabricius 1798, Betaeus Dana 1852 and Synalpheus Spence Bate 1888 (e. g., 
Fernandéz-Muñoz and Garcia-Raso 1987; Corey and Reid 1991; Lardies and Wehrtmann 1997, 2001; Mossolin et al. 2006; Lardies et al. 2008; Pavanelli et al. 2008, 2010; Harikrishnan et al. 2010; Costa-Souza et al. 2014; Rebolledo et al. 2014; Pescinelli et al. 2017).

The western Atlantic snapping shrimp A. carlae is a common representative of the $A$. armillatus H. Milne Edwards, 1937 [in H. Milne Edwards 1834-1840] species complex found along the Brazilian coast. Alpheus buckupi Almeida, Terossi, Araújo-Silva \& Mantelatto, 2013a is an amphiAtlantic species and its distribution in the western Atlantic overlaps with that of $A$. carlae Anker 2012 (see Anker 2012; Almeida et al. 2013a). Although A. buckupi shares some morphological similarities with species of the A. armillatus complex, it belongs to the A. lobidens de Haan 1850 complex (see Almeida et al. 2013a).

In northeastern Brazil, these two snapping shrimps are frequently observed co-existing in the field, living under rocks in the intertidal (e. g., Almeida et al. 2013b). There is evidence from southeastern Brazil that sympatric species may adopt distinct reproductive strategies [Pavanelli et al. 2008, A. carlae; Pavanelli et al. 2010, A. nuttingi (Schmitt 1924)]. On the other hand, there is a lack of studies with populations of the northeast coast. Some biological aspects of $A$. carlae have been studied (Pavanelli et al. 2008; Mossolin et al. 2006, as $A$. armillatus), however, knowledge on its biology is still very scarce. Alpheus buckupi was recently described and little is known about it. The sympatric distribution of such frequently co-existing shrimps raises an interesting question: do these lineages differ regarding reproductive features related to embryo production (fecundity, embryo volume, and reproductive output)? Thus, the objective of this study was to investigate, by means of a comparative approach, the characteristics of embryo production of two species of Alpheus found along the coast of Bahia, northeastern Brazil, and to contribute to the knowledge of these species' biology and to the reproductive biology of alpheids in general.

\section{Materials and Methods}

Sampling was conducted on four occasions between July 2012 and May 2013 at two locations on the coast of Bahia, northeastern Brazil [Moreré, Cairu (August 2012 and May 2013) and Itacaré (July 2012 and March 2013)] (Fig. 1). Specimens of A. buckupi and A. carlae were collected at Praia de Moreré, Boipeba Island, municipality of Cairu $\left(13^{\circ} 36^{\prime}\right.$ 49.5"S $\left.38^{\circ} 54^{\prime} 16.2^{\prime \prime} \mathrm{W}\right)$. Additional samples of $A$. carlae were taken at Praia da Concha, municipality of Itacaré $\left(14^{\circ} 16^{\prime} 31.4^{\prime \prime}\right.$ S $\left.38^{\circ} 59^{\prime} 14.5^{\prime \prime} \mathrm{W}\right)$.

Brooding females were collected by hand or with the use of small hand nets in tide pools, under rocks on soft bottoms, during low tides. The individuals were separated and placed in plastic bags containing water from the collection site. The species were separated based on their color pattern, and later the identification was confirmed by morphology (Anker 2012; Almeida et al. 2013b). The shrimps were anesthetized on ice and kept frozen until the analyses.

In the laboratory, the embryos of each female were carefully removed from the pleopods using a thin brush and tweezers. The embryos were classified according to their stage of embryonic development, following the classification of Mossolin et al. (2006): initial (I - embryos without visible eyes; yolk occupying more than $75 \%$ of the embryo volume), intermediate (II - embryos with small and elongated eyes; yolk occupying $50-75 \%$ of the embryo volume) and final (III - embryos with well-developed eyes and yolk occupying $25-50 \%$ of the embryo volume). Only normal (apparently viable) embryos were observed. Embryos with abnormal features such as those previously observed in A. estuariensis Christoffersen 1984 (see Costa-Souza et al. 2014) were not observed. Females and embryos were photographed under a stereoscopic microscope with an image capture system. The photos and the software ImageJ (1.45 s) were used to calculate the carapace length (CL), and the longest and shortest embryo diameters (Rasband 2006). The CL was measured from the tip of the rostrum to the posterior edge of the carapace. Females with embryos in stage I were oven-dried at $50{ }^{\circ} \mathrm{C}$ until constant weight was reached. The same procedure was adopted for the embryo masses (about $48 \mathrm{~h}$ for females and $24 \mathrm{~h}$ for embryo masses). The dried material was then weighed on an analytical balance with a precision of four decimal places (Mantelatto et al. 2002).

Fecundity was obtained based on the mean number of embryos. Mean embryo volume was based on 10 embryos from each female and calculated using the formula $\left[v=1 /{ }_{6} \times \pi \times(\mathrm{d} 1)^{2} \times \mathrm{d} 2\right]$ where $\mathrm{d} 1$ and $\mathrm{d} 2$ correspond to the longest and shortest diameters, respectively (Bauer 1991). Due to the low number of females with embryos in stages II and III, a larger number of embryos (25 maximum) per female were measured in these cases. The reproductive output (RO) was calculated as the ratio of the dry weight of the embryo mass to the dry weight of the female (Clarke et al. 1991). Only embryos in the initial stage of development (Stage I) were used to calculate fecundity and RO. Possible differences in embryo number and volume during embryonic development were accessed by comparing embryo mean number and volume between the three stages; such methodology was adopted in previous studies of Alpheus spp. (e. g., Pavanelli et al. 2008, 2010; Costa-Souza et al. 2014; Pescinelli et al. 2017).

All data were tested for normality using the Shapiro-Wilk test. Nonparametric procedures were adopted. The 95\% significance level was adopted for all analyses. Samples of different collections were grouped due to the lack of statistical differences between them (after comparisons with the Kruskal-Wallis test). The differences between species 


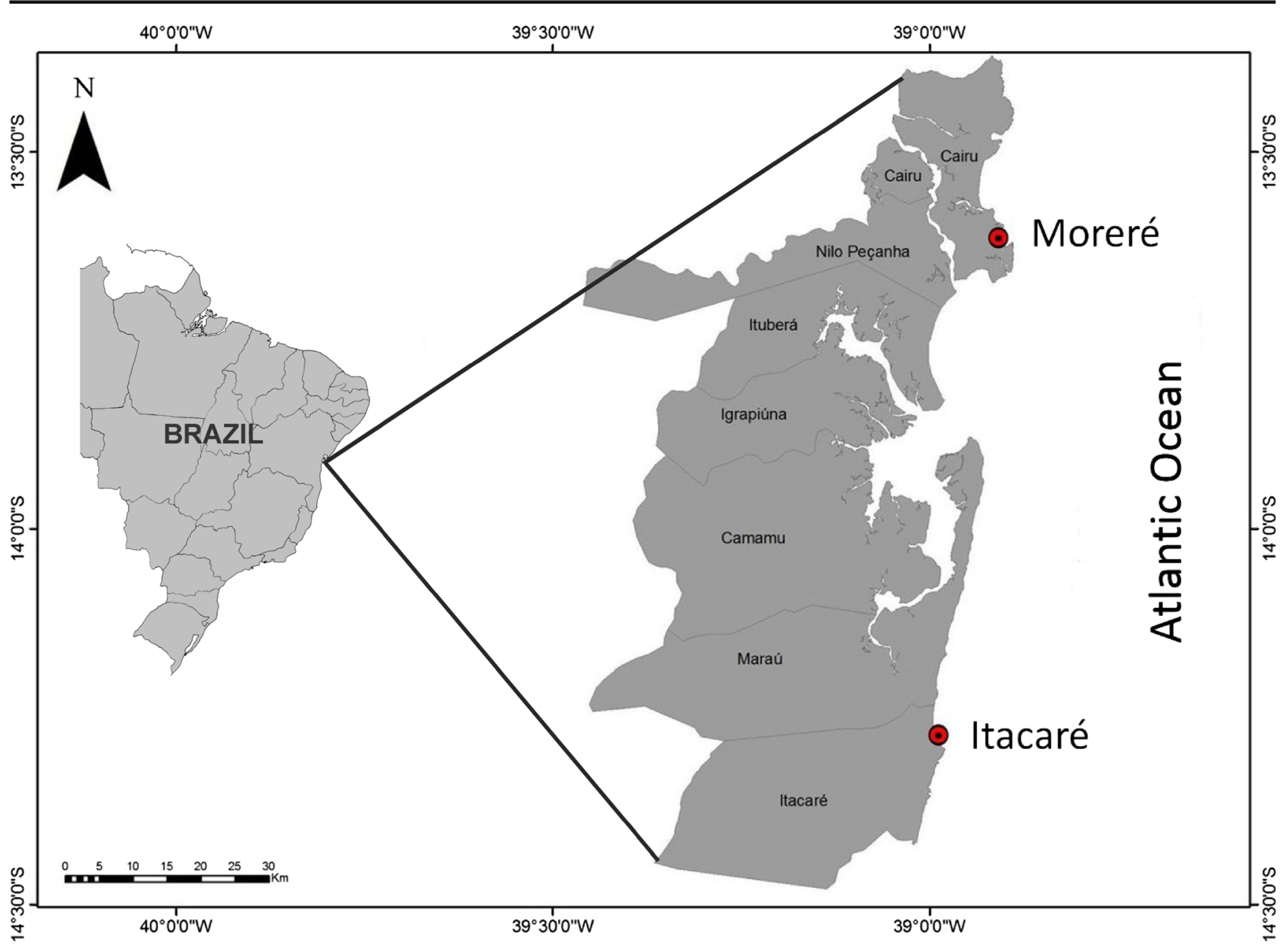

Fig. 1 Location of sampling sites (Moreré and Itacaré) of Alpheus buckupi Almeida et al. 2013a and Alpheus carlae Anker 2012 on the coast of Bahia, northeastern Brazil

regarding CL, fecundity, embryo volume, and RO were also tested using the Kruskal-Wallis test. Differences in fecundity and embryo volume were tested with an analysis of covariance (ANCOVA). The relationship between CL and fecundity was examined using the Spearman correlation coefficient. The CL was used as the independent variable in all analyses (Zar 1996). Statistical procedures were carried out using PAST (Paleontological Statistics 2.16).

Voucher specimens of both species were preserved in ethanol $70 \%$ and deposited in the carcinological collection of the Museum of Oceanography Professor Petrônio Alves Coelho, Universidade Federal de Pernambuco, Recife, Brazil (A. buckupi MOUFPE 15774; A. carlae MOUFPE 15875).

\section{Results}

A total of 47 A. buckupi and 36 A. carlae females carrying embryos were obtained. The CL was significantly larger in females of A. buckupi (9.4 $\pm 1.0 \mathrm{~mm}$, range: $6.8-12.0 \mathrm{~mm})$ than A. carlae ( $8.6 \pm 1.3 \mathrm{~mm}$; range: $6.7-12.1 \mathrm{~mm})$ (KruskalWallis, $p<0.05$ ).

Both fecundity and embryo volume differ significantly between both species (ANCOVA, $p<0.05$ ). The females of A. carlae had a lower fecundity $(50 \pm 58)$ and larger embryo volume $\left(0.13 \pm 0.03 \mathrm{~mm}^{3}\right)$ than $A$. buckupi, whose mean fecundity was $117 \pm 80$ and embryo volume was $0.10 \pm 0.03 \mathrm{~mm}^{3}$ (see Table 1). Overall, fecundity was correlated with female size in both $A$. buckupi and A. carlae $(r>0.5 ; p<0.05)$, (Fig. 2).

The number of embryos in developmental stages II and III in A. buckupi were lower than in stage I (Table 1). However, these differences were not significant (KruskalWallis, $p>0.05$ ). On the other hand, embryos in stages II and III were significantly larger than embryos in stage I (Kruskal-Wallis, $p<0.05$ ) (see Table 1). Comparisons between stages were not possible in A. carlae due to the low number of embryos in stages II and III. The mean RO did not differ significantly between $A$. buckupi and A. carlae $(0.05 \pm 0.06$ and $0.04 \pm 0.02$, respectively; Kruskal-Wallis, $p>0.05$ ) (Table 1). 
Table 1 Mean fecundity (number of embryos), embryo volume and reproductive output (RO) in Alpheus buckupi Almeida et al. 2013a and Alpheus carlae Anker 2012, from the coast of Bahia, northeastern Brazil, July 2012-May 2013

\begin{tabular}{|c|c|c|c|c|c|c|c|}
\hline & \multicolumn{3}{|c|}{ Number of embryos } & \multicolumn{3}{|c|}{ Embryo volume $\left(\mathrm{mm}^{3}\right)$} & \multirow[t]{3}{*}{ RO } \\
\hline & \multicolumn{3}{|c|}{ Stage of development } & \multicolumn{3}{|l|}{ Stage of development } & \\
\hline & I & II & III & I & II & III & \\
\hline A. buckupi & $117 \pm 80[32] \mathbf{a}$ & $114 \pm 69[4] \mathbf{a}$ & $113 \pm 95[11] \mathbf{a}$ & $0.10 \pm 0.03[287] \mathbf{a}$ & $0.13 \pm 0.03[30] \mathbf{b}$ & $0.13 \pm 0.05[100] \mathbf{b}$ & $0.05 \pm 0.06[19] \mathbf{a}$ \\
\hline A. carlae & $50 \pm 58[34] \mathbf{b}$ & $64[1]$ & $20[1]$ & $0.13 \pm 0.03[100] \mathbf{b}$ & - & - & $0.04 \pm 0.02[8] \mathbf{a}$ \\
\hline
\end{tabular}

Different letters $(\mathrm{a}$ or $\mathrm{b})=$ significant statistical difference; $\mathrm{N}=[]$.

\section{Discussion}

The inverse relationship between fecundity and embryo size observed in the species analyzed is the pattern commonly observed in alpheid shrimps (e. g., Pavanelli et al. 2008, 2010; Harikrishnan et al. 2010), as well as in other caridean shrimps (e. g., Clarke et al. 1991; Bauer 1991; Clarke 1993). Here, A. buckupi showed a higher investment in embryo production whereas brooding females of $A$. carlae produced fewer and larger embryos. Thus, as the population of $A$. buckupi was distinct from the population of $A$. carlae regarding embryo size and number, it may suggest different reproductive strategies.

The mode of larval development may influence the reproductive strategies followed by a species (see Bauer 1989). Wehrtmann and Albornoz (2002) observed differences between the reproductive strategies of the sibling species A. saxidomus Holthuis 1980 from Eastern Pacific, and A. simus Guérin-Méneville, 1855 from western Atlantic. These shrimps have different larval development patterns: The development of $A$. simus is abbreviated and the larvae hatch in a more advanced stage, the decapodid, whereas the development of $A$. saxidomus follows a more typical pattern for alpheids with several zoeal stages. The duration of embryonic development in crustaceans is directly related to embryo size due to the amount of yolk required to sustain the larval development until the first feeding stage, although this pattern is not seen in some species (see Bauer 1991). Larger and fewer embryos were observed in A. simus and attributed to the abbreviated development (Wehrtmann and Albornoz 2002). Such developmental features of A. simus are possibly an adaptation to the lower primary productivity of Caribbean waters that result in lower food availability during the larval development, as compared to eastern Pacific waters where A. saxidomus occurs (Wehrtmann and Albornoz 2002). However, differently from $A$. saxidomus - A. simus, differences in fecundity and embryo size between A. buckupi and A. carlae might not be directly related to different developmental strategies (see Strathmann 1977; Rabalais and Gore 1985). The larval development of both snapping shrimps remain to be investigated which prevents more precise explanations at this moment.

The influence of environmental factors on the reproductive strategy of different populations of the same species, or of allopatric species (as shown in the sibling species pair A. saxidomus $-A$. simus; Wehrtmann and Albornoz 2002) is well documented. Here we found differences between species coexisting in the intertidal zone. Different adaptive strategies
Fig. 2 Correlation between carapace length and fecundity (number of embryos) of two species of Alpheus Fabricius 1798 , from the coast of Bahia, northeastern Brazil, July 2012 May 2013
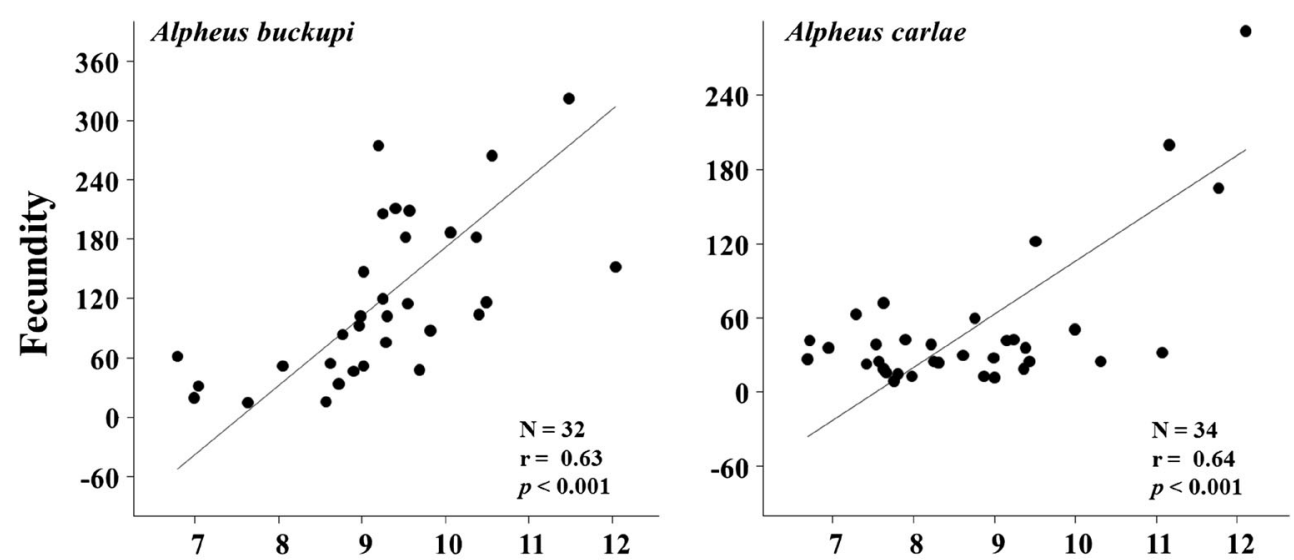

Carapace length (mm) 
apparently have been adopted by these shrimps, possibly to increase the allocation of resources for reproduction, or to reduce the impacts of predation on adults (in the intertidal zone) and to reduce larvae mortality (in the plankton). Furthermore, behavioral differences might also influence the reproduction of these sympatric species, such as advantages in the obtaining of energy resources for reproduction.

This adaptive advantage in obtaining resources can often be related to the size of individuals. The larger size of A. buckupi females can make them better competitors in relation to A. carlae females, which might result in a higher reproductive potential. Territoriality and agonistic behavior are recognized traits in some species of Alpheus (e. g., Nolan and Salmon 1970; Mathews 2002), and larger size might represent a competitive advantage over sympatric species regarding resource allocation for reproduction. Moreover, Bauer (1991) observed a positive allometric correlation between CL and embryo production in A. normanni Kingsley 1878, which suggests morphological or physiological adaptations that allow a higher reproductive output with the increase in female size. Indeed, differences in fecundity have been previously associated with the mean size of females. Pavanelli et al. (2010) observed higher embryo production in A. nuttingi in relation to one sympatric population of A. carlae from São Sebastião, São Paulo, and attributed this difference to the larger size of $A$. nuttingi. Therefore, the larger size of A. buckupi females would explain the higher embryo production, as compared to A. carlae.

The populations studied here had low fecundity in relation to other species of the genus. Even the mean fecundity found in A. buckupi (117 \pm 80 embryos) is below the values of other congeners (Table 2). Again, the female size might be the main factor involved here. In caridean shrimps, which incubate embryos under the abdomen, the larger the body size, the greater the capacity for carrying embryos (Bauer 1991). The brooding females analyzed in this study have the smallest mean size among all females of species of Alpheus studied so far (Table 2). Their fecundity is only higher when compared to the fecundity of small species of alpheid shrimps (Table 2). Species of Synalpheus, for example, produce fewer embryos in comparison to genera that include larger species, such as Alpheus and Betaeus (see Table 2). These differences might initially be related to size of the species within each genus. Furthermore, species with direct or abbreviated development tend to produce larger and fewer embryos (Wehrtmann and Albornoz 2002). This is the pattern observed in Synalpheus, especially in eusocial species (Corey and Reid 1991; Duffy 1996).

The fecundity and reproductive output of the A. carlae population from Bahia are lower than those found for a population from southeastern Brazil (Pavanelli et al. 2008). Variation between populations of species with wide distribution has been attributed to latitudinal factors and food availability (e. g., Lardies and Wehrtmann 2001; Lardies et al. 2008; Mantelatto et al. 2010; Wehrtmann et al. 2011). The increase in embryo volume in populations from higher latitudes of the alpheid Betaeus truncatus Dana 1852 from the Chilean coast was related to higher protection (i. e., thermal isolation) against lower water temperatures (Lardies and Wehrtmann 2001).

Populations of alpheid shrimps in lower latitudes reproduce continuously throughout the year (e. g., A. normanni; see Bauer 1989) whereas populations in higher latitudes tend to reproduce seasonally (e. g., S. fritzmuelleri Coutière 1909 and S. apioceros Coutière 1909; see Felder 1982). Other alpheids such as A. carlae (Mossolin et al. 2006), S. longicarpus (Herrick 1891), S. brooksi Coutière 1909 and S. pectiniger Coutière 1907 (Erdman and Blake 1987) have continuous reproduction with peaks at certain times. Due to energy costs, species that reproduce continuously tend to allocate less energy to each reproductive event. This would be a further explanation for the lower fecundity and RO observed here in comparison with the studies performed on the southeastern coast of Brazil. However, the possibility that the populations analyzed adopt the strategy of multiple spawning throughout the year remains to be tested.

Our data indicate a low embryo loss during incubation in A. buckupi. In caridean shrimps, the percentage of embryo loss from the first to the final stage of embryo development might exceed 30\% (Corey and Reid 1991; Lardies and Wehrtmann 1997). This might be due to the increase in embryo volume during development, which leads to losses, especially of embryos placed on the outer side of brood masses (Corey and Reid 1991). Behavioral factors, such as intraspecific agonistic interactions or escape from predators might also contribute to embryo loss (see Pavanelli et al. 2010). However, the cryptic habits of alpheid shrimps and their heterosexual pairing behavior might reduce the intensity of these factors (Pavanelli et al. 2010).

The embryos differ substantially in volume and shape throughout development in A. buckupi (33\% of total increase). This increase is similar to that found for a population of A. brasileiro Anker 2012 from Cananéia, southeastern Brazil (35.4\%, Pescinelli et al. 2017). Although, this percentage is smaller than that observed in A. carlae (64.3\%) and A. nuttingi (87.4\%) populations of southeastern Brazil (Pavanelli et al. 2008, 2010). In other alpheids, the final increment might be even higher (up to $200 \%$; Lardies and Wehrtmann 1997, 2001). The main reason for this increase is the absorption of water by the embryos during incubation (Lardies and Wehrtmann 1997). In addition, the embryos acquire a more oval shape, especially in stage III, in contrast to the more rounded shape of stage I. These changes in embryo shape have been previously reported for the group and are common in decapods (Pavanelli et al. 2008, 2010). 
Table 2 Female size (CL), fecundity, embryo volume (EV), and reproductive output (RO) of alpheid shrimps

\begin{tabular}{|c|c|c|c|c|c|c|c|c|c|}
\hline & \multirow[t]{2}{*}{$\mathrm{N}$} & \multicolumn{2}{|l|}{ CL } & \multicolumn{2}{|l|}{ Fecundity } & \multirow[t]{2}{*}{ EV } & \multirow[t]{2}{*}{ RO } & \multirow[t]{2}{*}{ Locality } & \multirow[t]{2}{*}{ Reference } \\
\hline & & Min. & Max. & Min. & Max. & & & & \\
\hline McClure 2002 & 11 & 4.78 & 7.02 & 9 & 48 & 0.13 & - & Bahia, Brazil & Present study \\
\hline \multirow[t]{2}{*}{ Alpheus armillatus } & 4 & 7.4 & 8.8 & 145 & 504 & 0.18 & - & Florida, USA & Corey and Reid (1991) \\
\hline & 6 & 6.29 & 9.34 & 27 & 43 & 0.13 & - & Bahia, Brazil & Present study \\
\hline Alpheus brasileiro & 28 & 5.30 & 8.37 & $149 \pm 93$ & 0.12 & - & & São Paulo, Brazil & Pescinelli et al. 2017 \\
\hline Alpheus buckupi & 47 & 6.79 & 12.04 & 32 & 322 & 0.10 & 0.06 & Bahia, Brazil & Present study \\
\hline Alpheus carlae & 36 & 6.69 & 12.1 & 12 & 83 & 0.13 & 0.04 & Bahia, Brazil & Present study \\
\hline Alpheus carlae (as A. armillatus) & 31 & 7.7 & 14.1 & 42 & 1979 & 0.10 & 0.12 & São Paulo, Brazil & Pavanelli et al. (2008) \\
\hline Alpheus dentipes Guérin 1832 & - & & & - & 836 & - & - & Málaga, Spain & $\begin{array}{c}\text { Fernandéz-Muñoz and } \\
\text { Garcia-Raso (1987) }\end{array}$ \\
\hline Alpheus estuariensis & 46 & 7.5 & 12.2 & 33 & 443 & 0.11 & - & Bahia, Brazil & Costa-Souza et al. (2014) \\
\hline $\begin{array}{l}\text { Alpheus euphrosyne euphrosyne } \\
\text { de Man } 1897\end{array}$ & 41 & 11.0 & 19.2 & 141 & 1553 & 0.004 & 0.18 & Cochin, India & Harikrishnan et al. (2010) \\
\hline Alpheus glaber (Olivi 1792) & 15 & 8.5 & 10 & 180 & 330 & - & - & Off Ancona, Central Adriatic & Atkinson et al. (2003) \\
\hline Alpheus heterochaelis Say 1818 & 5 & 10.0 & 13.4 & 133 & 336 & 0.91 & - & Florida, USA & Corey and Reid (1991) \\
\hline Alpheus normanni & 7 & 10.0 & 17.4 & 68 & 584 & 0.09 & - & Florida, USA & Corey and Reid (1991) \\
\hline Alpheus normanni & 35 & 4.1 & 7.4 & - & - & 0.03 & - & Puerto Rico & Bauer (1991) \\
\hline Alpheus nuttingi & 27 & 11.0 & 18.6 & 949 & 4222 & 0.09 & 0.07 & São Paulo, Brazil & Pavanelli et al. (2010) \\
\hline Alpheus saxidomus & 5 & 10.1 & 17.4 & - & - & 0.25 & 0.44 & Costa Rica & Wehrtmann and Graeve (1998) \\
\hline $\begin{array}{l}\text { Betaeus emarginatus } \\
\quad \text { (H. Milne Edwards, 1837) }\end{array}$ & 38 & 9.0 & 16.3 & 94 & 615 & 0.21 & 0.09 & Valdivia, Chile & Lardies and Wehrtmann (1997) \\
\hline Betaeus truncatus & 25 & 5.3 & 11.7 & - & 1067 & 0.06 & 0.07 & Guanaquero, Chile & Lardies and Wehrtmann (2001) \\
\hline Betaeus truncatus & 19 & - & 8.9 & - & 498 & 0.09 & 0.13 & Metri, Chile & Lardies and Wehrtmann (2001) \\
\hline Betaeus truncatus & 57 & 6.54 & - & - & 731 & 0.10 & 0.18 & Putemún, Chile & Lardies and Wehrtmann (2001) \\
\hline $\begin{array}{l}\text { Synalpheus agelas Pequegnat } \\
\text { and Heard } 1979\end{array}$ & 5 & 4.2 & 5.6 & 16 & 65 & 0.27 & - & Gulf of Mexico & Corey and Reid (1991) \\
\hline Synalpheus apioceros & 46 & 3.8 & 7.4 & 8 & 310 & - & 0.18 & Bocas del Toro, Panama & Rebolledo et al. (2014) \\
\hline Synalpheus brooksi & 10 & 3.4 & 4.5 & 3 & 11 & 0.50 & - & Florida, USA & Corey and Reid (1991) \\
\hline Synalpheus herricki Coutière 1909 & 4 & 3.5 & 5.1 & 11 & 81 & 0.22 & - & Florida, USA & Corey and Reid (1991) \\
\hline Synalpheus fritzmuelleri & 13 & 3.8 & 6.5 & 39 & 484 & 0.09 & - & Florida, USA & Corey and Reid (1991) \\
\hline Synalpheus longicarpus & 21 & 5.5 & 8.0 & 27 & 349 & 0.17 & - & Florida, USA & Corey and Reid (1991) \\
\hline Synalpheus pectiniger & 31 & 3.5 & 4.6 & 4 & 17 & 0.75 & - & Florida, USA & Corey and Reid (1991) \\
\hline $\begin{array}{l}\text { Synalpheus yano (Ríos and Duffy } \\
\text { 2007) }\end{array}$ & 84 & 3.7 & 9.6 & 6 & 246 & 0.06 & 0.51 & & Hernaez et al. (2010) \\
\hline
\end{tabular}

The RO of A. buckupi and A. carlae, both around 5\% of female body mass, are low compared with other alpheids (Table 2). Previously studied alpheids showed values around $10 \%$ (Table 2). Reproductive investment seems to follow an increasing gradient towards high latitudes (e. g., Lardies and Wehrtmann 2001; Lardies et al. 2008). Alpheid shrimps also seem to follow this pattern (Table 2). The low RO value observed in this study for $A$. carlae compared to the population studied in southeastern Brazil (Pavanelli et al. 2008) might also be related to latitudinal factors. Alpheus buckupi has not been previously studied, therefore, other populations along the latitudinal gradient need to be analyzed in future studies to verify the relationship between RO and latitude.
Our results indicate that reproductive features differ between sympatric lineages. Alpheus buckupi invests more in the number of embryos, whereas $A$. carlae has lower fecundity and higher embryonic volume. These differences suggest that the reproductive strategies of these shrimps are under the influence of different selective forces even though, as sympatric species, they are exposed to similar environmental pressures. This seems to be related to female size differences among species in which the larger size of A. buckupi might grant it a competitive advantage, influencing fecundity. The present study provides the first insights on the embryo production of $A$. buckupi in the Western Atlantic and of $A$. carlae in northeastern Brazil. 
Acknowledgments The authors are grateful to the Programa de PósGraduação em Zoologia of UESC for its support; to Drs. Fernando L. Mantelatto and Luis E. A. Bezerra for their criticisms on the Master Thesis that originated this contribution, and to Mario V. Oliveira for helping in the field work. Finally, the authors thank to Dr. Raymond Bauer for his comments on an earlier version of the manuscript.

\section{Compliance with Ethical Standards}

Financial Support The authors acknowledge Fundação de Amparo à Pesquisa do Estado da Bahia (FAPESB) (APP 0035/2011) and Universidade Estadual de Santa Cruz (00220.1100.1065) for financing the project "Biologia e Ecologia de Camarões da Família Alpheidae (Crustacea: Decapoda: Caridea)". GOS and PSS thanks Coordenação de Aperfeiçoamento de Pessoal de Nível Superior (CAPES) for the provision of Master scholarships. RCC and AOA thank Conselho Nacional de Desenvolvimento Científico e Tecnólogico (CNPq) for the Research Scholarships 305,919/2014-8 and 305,939/2015-7, respectively.

Disclosure Statement On behalf of all authors, the corresponding author states that there is no conflict of interest.

\section{References}

Almeida AO, Terossi M, Araújo-Silva CL, Mantelatto FL (2013a) Description of Alpheus buckupi spec. nov., a new amphi-Atlantic snapping shrimp (Caridea: Alpheidae), based on morphological and molecular data. Zootaxa 3652:437-452

Almeida AO, Costa-Souza AC, Cunha AM, Santos PS, Oliveira MV, Soledade GO (2013b) Estuarine caridean shrimps (Crustacea: Decapoda) from Ilhéus, Bahia, Brazil: updated checklist and a key for their identification. Check List 9:1396-1405

Anker A (2012) Revision of the western Atlantic members of the Alpheus armillatus H. Milne Edwards, 1837 species complex (Decapoda, Alpheidae), with description of seven new species. Zootaxa 3386: $1-109$

Anker A, Ahyong ST, Noel PY, Palmer AR (2006) Morphological phylogeny of alpheid shrimps: parallel preadaptation and the origin of a key morphological innovation, the snapping claw. Evolution 60: 2507-2528

Atkinson RJA, Gramitto ME, Froglia C (2003) Aspects of the biology of the burrowing shrimp Alpheus glaber (Olivi) (Decapoda: Caridea: Alpheidae) from the central Adriatic. Ophelia 57:27-42

Bauer RT (1989) Continuous reproduction and episodic recruitment in nine shrimp species inhabiting a tropical seagrass meadow. J Exp Mar Biol Ecol 127:175-187

Bauer RT (1991) Analysis of embryo production in a caridean shrimp guild from a tropical seagrass meadow. In: Wenner A, Kuris A (eds) Crustacean egg production, Crustacean Issues, vol 7. Balkema Press, Rotterdam, pp 181-191

Chace FA Jr (1988) The caridean shrimps (Crustacea: Decapoda) of the albatross Philippine Expedition, 1907-1910, part 5: family Alpheidae. Smithsonian Contribuitions to Zoology 466:1-99

Christoffersen ML (1984) The western Atlantic snapping shrimps related to Alpheus heterochaelis say (Crustacea, Caridea) with the description of a new species. Papéis Avulsos de Zoologia 35:189-208

Clarke A (1993) Reproductive trade-off s in caridean shrimps. Funct Ecol 7:411-419

Clarke A, Hopkins CCE, Nilssen EM (1991) Egg size and reproductive output in the deep water prawn Pandalus borealis Kroyer, 1838. Funct Ecol 5:724-730
Corey S, Reid DM (1991) Comparative fecundity of decapod crustaceans. I. The fecundity of thirty-three species of nine families of caridean shrimp. Crustaceana 60:270-294

Costa-Souza AC, Rocha SS, Bezerra LEA, Almeida AO (2014) Breeding and heterosexual pairing in the snapping shrimp Alpheus estuariensis (Caridea: Alpheidae) in a tropical bay in northeastern Brazil. J Crustac Biol 34:593-603

Coutière H (1907) Sur la presence de males em exces chez deux espèces de Synalphées. Comptes Rendus hebdomadaires des Séances et Mémoires de la Société de Biologie 62:610-612

Coutière H (1909) The American species of snapping shrimps of the genus Synalpheus. Proceedings of the United States National Museum 36:1-93

Dana JD (1852) Conspectus Crustaceorum \&C. conspectus of the Crustacea of the exploring Expedition under Capt. C. Wilkes, U.S.N. Macroura. Proc Acad Natl Sci Phila 1852:10-29

de Haan W (1833-1850) Crustacea. In: von Siebold PF (ed) Fauna japonica sive Descriptio Animalium, quae in Itinere per Japoniam, Jussu et Auspiciis Superiorum, qui Summum in India Batava imperium Tenent, Suspecto, Annis 1823-1830 Collegit, Notis, Observationibus et Adumbrationibus Ilustravit: i-xxxi, ix-xvi, 1243, Plates A-J, L-Q, 1-55. Lugduni-Batavorum

de Man JG (1897) Bericht über die von Herrn Schiffscapitän Storm zu Atjeh, an den westlichen Küsten von Malakka, Borneo und Celebes sowie in der Java-See gesammelten Decapoden und Stomatopoden. Fünfter Theil. Zoologische Jahrbücher. Abtheilung für Systematik, Geographie und Biologie der Thiere 9:725-790

Duffy JE (1996) Eusociality in a coral-reef shrimp. Nature 381:512-514

Erdman RB, Blake NJ (1987) Population dynamics of the spongedwelling alpheid Synalpheus longicarpus, with observations on $S$. brooksi and S. pectiniger, in shallow-water assemblages of the eastern Gulf of Mexico. J Crustac Biol 7:328-337

Fabricius JC (1798) Supplementum Entomologiae Systematicae: 1-572. Hafniae: Proft et Storch.

Felder DL (1982) Reproduction of the snapping shrimps Synalpheus fritzmuelleri and $S$. apioceros (Crustacea: Decapoda: Alpheidae) on a sublittoral reef off Texas. J Crustac Biol 2:535-543

Fernandéz-Muñoz R, Garcia-Raso JE (1987) Study of a population of Alpheus dentipes Guerin, 1832 from calcareous bottoms in the southern Spain. Investigaciones Pesqueras 51(1):343-359

Guérin FE (1832) I. Classe. Crustacés, arachnids et Insectes. In Voyage autour du monde, execute par Ordre du Roi, sur la Corvette de sa majesté, La Coquille, pendant les années 1822, 18231824 et 1825. Duperry LI, pp 1-47

Harikrishnan M, Unnikrishnan U, Maju MS, Greeshma ARR, Kurup BM (2010) Size at sexual maturity, egg number and reproductive output of the snapping shrimp Alpheus euphrosyne euphrosyne de man, 1897. Invertebr Reprod Dev 54:195-202

Hartnoll RG (1985) Growth, sexual maturity and reproductive output. In: Wenner A (ed) Factors in adult growth, Crustacean Issues, vol 3. A.A. Balkema, Rotterdam, pp 101-128

Hernáez P, Martínez-Guerrero B, Anker A, Wehrtmann IS (2010) Fecundity and effects of bopyrid infestation on egg production in the Caribbean sponge-dwelling snapping shrimp Synalpheus yano (Decapoda: Alpheidae). J Mar Biol Assoc U K 90(04):691-698

Herrick FH (1891) Alpheus: a study in the development of Crustacea. In: Brioks WK, Herrick FH (eds) The embryology and metamorphosis of the Macroura, vol 5. Memoirs of the National Academy of Sciences, Washington, pp 370-463

Holthuis LB (1980) Alpheus saxidomus new species, a rock boring snapping shrimp from the Pacific coast of Costa Rica, with notes on Alpheus simus Guérin-Méneville, 1856. Zoologische Mededelingen 55:47-58

Kingsley JS (1878) A synopsis of the north American species of the genus Alpheus. Bulletin of the United States Geological and Survey of the Territories 4:189-199 
Lardies M, Wehrtmann IS (1997) Egg production in Betaeus emarginatus (H. Milne Edwards, 1837) (Decapoda: Alpheidae): fecundity, reproductive out-put and chemical composition of eggs. Ophelia 46:165174

Lardies M, Wehrtmann IS (2001) Latitudinal variation in the reproductive biology of Betaeus truncatus (Decapoda: Alpheidae) along the Chilean coast. Ophelia 55:55-67

Lardies MA, Medina MH, Correa JA (2008) Intraspecific biogeographic pattern breakage in the snapping shrimp Betaeus emarginatus caused by coastal copper mine tailings. Mar Ecol rog Ser 358: 203-210

Mantelatto FLM, Alarcon VF, Garcia RB (2002) Egg production strategies of the tropical hermit crab Paguristes tortugae from Brazil. J Crustac Biol 22:390-397

Mantelatto FLM, Fernandes-Góes LC, Fantucci MZ, Biagi R, Pardo LM, Góes JM (2010) A comparative study of population traits between two south American populations of the striped-legged hermit crab Clibanarius vittatus. Acta Oecol 36:10-15

Mathews L (2002) Territorial cooperation and social monogamy: factors affecting intersexual behaviours in pair-living snapping shrimp. Anim Behav 63:767-777

Milne Edwards H (1834-1840) Histoire naturelle des Crustacés, comprenant l'anatomie, la physiologie et la classification de ces animaux: $1-468,1-532,1-638,1-32$. Paris: Librairie encyclopédique de Roret.

Mossolin EC, Shimizu RM, Bueno SLS (2006) Population structure of Alpheus armillatus (Decapoda, Alpheidae) in São Sebastião and Ilhabela, southeastern Brazil. J Crustac Biol 26:48-54

Nolan BA, Salmon M (1970) The behavior and ecology of snapping shrimp (Crustacea: Alpheus heterochelis and Alpheus normanni). Forma et Function 2:289-336

Olivi G (1792) Zoologia Adriatica ossia Catalogo ragionata degli Animal del Golfo e delle Laguna di Venezia; preceduto da una Dissertazione sulla Storia fiscia e natural del Golfo; e accompagnato da Memorie, ed Osservazioni di Fiscia Storia natural ed Economia: i-xxxiii, 1334, Plates 1-9. Bassano

Pavanelli CAM, Mossolin EC, Mantelatto FL (2008) Reproductive strategy of the snapping shrimp Alpheus armillatus H. Milne Edwards, 1837 in the South Atlantic: fecundity, egg features and reproductive output. Invertebr Reprod Dev 52:123-130

Pavanelli CAM, Mossolin EC, Mantelatto FL (2010) Maternal investment in egg production: environmental and population-specific effects on offspring performance in the snapping shrimp Alpheus nuttingi (Schmitt, 1924) (Decapoda, Alpheidae). Anim Biol 60: 237-247

Pequegnat LH, Heard RW (1979) Synalpheus agelas, new species of snapping shrimp from the Gulf of Mexico and Bahama Islands (Decapoda: Caridea: Alpheidae). Bull Mar Sci 29:110-116
Pescinelli RA, Davanso TM, Costa RC (2017) Social monogamy and egg production in the snapping shrimp Alpheus brasileiro (Caridea: Alpheidae) from the south-eastern coast of Brazil. J Mar Biol Assoc U K. doi:10.1017/S0025315416000904

Rabalais NN, Gore RH (1985) Abbreviated development in decapods. In: Wenner AM (ed) Larval growth. A.A. Balkema, Rotterdam, pp 67-126

Rafinesque CS (1815) Analyse de la Nature ou Tableau de l'Univers et des corps organisés:1-224. Palerme

Rasband WS (2006) ImageJ: image processing and analysis in java. National Institutes of Health, Research Services Branch, Bethesda.

Rebolledo AP, Wehrtmann IS, Felder DL, Mantelatto FLM (2014) Embryo production in the sponge-dwelling snapping shrimp Synalpheus apioceros (Decapoda, Alpheidae) from Bocas del Toro, Panama. Zookeys 457:227-238

Ríos R, Duffy JE (2007) A review of the sponge-dwelling snapping shrimp from Carrie Bow Cay, Belize, with description of Zuzalpheus, new genus, and six new species. Zootaxa 1602:1-89

Sastry AN (1983) Ecological aspects of reproduction. In: Vernberg FJ, Vernberg EB (eds) The biology of Crustacea. Environmental Adaptations, vol 8. Academic Press, New York, pp 179-270

Say T (1818) An account of the Crustacea of the United States, part 5. J Acad Natl Sci Phila 1:235-253

Schmitt WL (1924) Report on the Macrura, Anomura and Stomatopoda collected by the Barbados-Antigua Expedition from the University of Iowa in 1918. University of Iowa Studies of Natural History 10: 65-99. plates $1-5$

Spence Bate C (1888) Report on the Crustacea Macrura collected by the Challenger during the years 1873-76. Report on the Scientific Results of the Voyage of H.M.S. "Challenger" during the years 1873-76, 24, 1-942

Strathmann RR (1977) Egg size, larval development, and juvenile size in benthic marine invertebrates. Am Nat 111:373-376

Wehrtmann IS, Albornoz L (2002) Evidence of different reproductive traits in the transisthmian sister species, Alpheus saxidomus and A. simus (Decapoda, Caridea, Alpheidae): description of the first postembryonic stage. Mar Biol 140:605-612

Wehrtmann IS, Graeve M (1998) Lipidic composition and utilization in developing eggs of two tropical marine caridean shrimps (Decapoda: Caridea: Alpheidae, Palaemonidae). Comp Biochem Physiol 121:457-463

Wehrtmann IS, Miranda I, Lizana-Moreno A, Hernáez P, BarrantesEchandi V, Mantelatto FL (2011) Reproductive plasticity in Petrolisthes armatus (Anomura, Porcellanidae): a comparison between a Pacific and Atlantic population. Helgol Mar Res 66:87-96

Zar JH (1996) Biostatistical analysis. Prentice Hall, Upper Saddle River, $662 \mathrm{pp}$ 